\title{
Erratum to: Measuring Environmental Performance Under Regional Heterogeneity in China: A Metafrontier Efficiency Analysis
}

\author{
Yanni Yu ${ }^{1} \cdot$ Yongrok Choi $^{2}$
}

Published online: 30 September 2015

(C) Springer Science+Business Media New York 2015

\section{Erratum to: Comput Econ (2015) 46:375-388 DOI 10.1007/s10614-014-9464-5}

The first author of this article, Yanni Yu has changed her affiliation.

The online version of the original article can be found under doi:10.1007/s10614-014-9464-5.

\section{Yongrok Choi}

yrchoi@inha.ac.kr

Yanni Yu

a-yuyanni@hotmail.com; yayabaobei@naver.com

1 Institute of Resource, Environment and Sustainable Development, School of Economics, Jinan University, Guangzhou 510632, Guangdong, China

2 Department of International Trade and Regional Studies, Inha University, Inharo100, Nam-gu, Incheon 402-751, Korea 